\title{
VULNERABILIDADE SOCIAL: práticas e desafios em escolas públicas de educação básica
}

\author{
SOCIAL VULNERABILITY: practices and challenges in public \\ schools of basic education
}

\section{VULNERABILIDAD SOCIAL: prácticas y retos en escuelas públicas de educación básica}

\author{
Flávia Obino Corrêa Werle* \\ ORCID: https://orcid.org/0000-0001-5795-2537 \\ Maria José Santos da Silva** \\ ORCID: http://orcid.org/0000-0002-8748-9835
}

\begin{abstract}
Resumo: O artigo caracteriza vulnerabilidade como um processo dinâmico situado entre inclusão e exclusão para então discutir características do Programa Bolsa Família pela análise de fontes variadas como legislação, relatórios e boletins. A seguir apresenta pesquisa realizada em Município da Grande Porto Alegre considerando dois níveis de práticas de gestão: (a) práticas que a rede municipal cria para lidar com situações de estudantes beneficiários do PBF; (b) práticas que equipes diretivas criam para enfrentar desafios e desenvolverem ações de gestão comprometidas com a comunidade, seus estudantes e a democratização da educação. A metodologia é de cunho qualitativo, relacionada ao interacionismo simbólico e discussão em grupo de membros de equipes diretivas de algumas escolas com grande quantidade de estudantes beneficiários do PBF. Dentre os desafios estão questões voltadas para a permanência dos estudantes nas escolas; a distorção idadesérie e o manejo dos casos de infrequência. Tais desafios estão relacionados aos contextos de vulnerabilidade social, à presença de ilícitos de diversos tipos, incluindo o uso de drogas e guerra entre facções que, muitas vezes, levam as famílias a mudarem de residência.
\end{abstract}

Palavras-chave: Programa Bolsa Família. Gestão escolar. Escola pública.

Abstract: The article characterizes vulnerability as a dynamic process between inclusion and exclusion and then discusses characteristics of the BFP-Bolsa Família Program (Family Allowance Program), by analyzing various sources, such as legislation, reports and students report cards. Next a survey performed in a Greater Porto Alegre municipality is discussed, considering two levels of management practices: (a) practices created by the municipal network to deal with situations regarding students who are the beneficiaries of the BFP; (b) practices created by management teams to deal with challenges and develop management actions committed to the community, its students and democratization of education. The methodology is qualitative and related to symbolic interactionism and group discussion by members of the management teams of some schools where many students are BFP beneficiaries. Among the challenges are the need to get the forces of the

\footnotetext{
* Professor titular da Universidade do Vale do Rio dos Sinos, atuando no Programa de Pós-Graduação em Educação, orientadora de doutorado e mestrado. Exerce também docência e orientação no Mestrado Profissional em Gestão Educacional do qual foi coordenadora de março de 2015 até julho de 2017. É vice presidente da Sociedade Brasileira de Educação Comparada, bolsista produtividade 1A do CNPq, CA-ED. Email: flaviaw@2015@gmail.com.

** Doutoranda em Educação na Linha de Pesquisa Educação, História e Política pela Universidade do Vale do Rio dos Sinos - UNISINOS/RS, Mestra em Educação pela Universidade Federal de Alagoas (UFAL), Especialista em Gestão Escolar (UFAL) e Graduada em Pedagogia (UFAL). Possui experiência na área da Educação em: docência, gestão escolar e coordenação pedagógica.
} 
school community to take action considering the efforts at democratization and aimed at keeping the students in school; the age-grade distortion and the management of cases of non-attendance. These challenges are related to the contexts of social vulnerability, to the presence of various kinds of illegalities, including the use of drugs and warring among the factions, that often lead families to move from their homes.

Key words: Bolsa Família Program. School management. Public school.

Resumen: El artículo caracteriza vulnerabilidad como un proceso dinámico entre inclusión y exclusión para luego discutir las características del Programa Bolsa Familia a través del análisis de fuentes variadas como legislación, informes y boletines. A continuación, discute las investigaciones realizadas en municipio del Gran Porto Alegre considerando dos niveles de prácticas de gestión: (a) prácticas que crea la red municipal para atender situaciones de estudiantes beneficiarios por el PBF; (b) prácticas que equipos directivos crean para enfrentar desafíos y desarrollar acciones de gestión comprometidas con la comunidad, sus estudiantes y la democratización de la educación. La metodología es de carácter cualitativo, relacionada al interaccionismo simbólico y la discusión en grupo de miembros de equipos directivos de algunas escuelas con gran número de alumnos beneficiarios por el PBF. Entre los desafíos se encuentra la necesidad de activar las fuerzas de la comunidad escolar con miras a los esfuerzos de democratización y orientados para la permanencia de los estudiantes en las escuelas; la distorsión del grado de edad y el manejo de casos poco frecuentes. Dichos desafíos están relacionados con contextos de vulnerabilidad social, la presencia de actos ilícitos de diversa índole, incluyendo el consumo de drogas y la guerra entre facciones que, muchas veces, llevan a las familias a cambiar de residencia.

Palabras-clave: Programa Bolsa Familia. Gestión escolar. Escuela pública.

\section{INTRODUÇÃO}

Este texto compreende introdução, desenvolvimento e conclusão. A Introdução apresenta os objetivos do trabalho, e enfoques teóricos acerca de vulnerabilidade social e políticas de proteção social. No desenvolvimento desse artigo é discutida uma das políticas de proteção social não contributivas - o Programa Bolsa Família (PBF) -, em suas características e articulações com a educação. A seguir apresenta-se o PBF em dados do Estado do Rio Grande do sul, da Região Metropolitana de Porto Alegre e do Município de São Leopoldo (SL), local em que foi realizada a pesquisa empírica. Compõe também o Desenvolvimento a apresentação dos elementos teórico-metodológicos da pesquisa, as práticas criadas pela rede municipal e as de gestão escolar verbalizadas por ocasião da discussão em grupo da qual participaram equipes diretivas de algumas escolas municipais de SL. Por fim, é apresentado o fechamento do artigo na forma de Conclusões, ainda que não finais, bem como as referências bibliográficas.

Compreendendo que o conceito de vulnerabilidade social está posicionado num continuum entre inclusão e exclusão, esse artigo discute práticas de gestão em rede de educação básica relacionadas à política pública que alcança crianças e jovens designada de Programa Bolsa Família (PBF). Objetiva-se, assim, descrever e analisar práticas de gestão de uma rede municipal de educação básica do sul do 
país e de algumas de suas escolas, considerando dois níveis: (a) práticas que a rede municipal cria para lidar institucionalmente com escolas que possuam estudantes em situação de vulnerabilidade social, e (b) práticas que as equipes diretivas constituem para enfrentar os desafios e desenvolverem ações de gestão comprometidas com a comunidade, seus estudantes e a democratização da educação.

A ideia de continuum sugere que vulnerabilidade social decorre de um processo dinâmico, relacionado a debilidades do vínculo social as quais não são constantes nem permanentes ademais, não existe "um conceito de vulnerabilidade social que seja absoluto, expresso num coeficiente universal" (RESENDE; RIBEIRO, 2017, p. 388). Por outro lado, acompanhando Janczura (2012), entende-se que vulnerabilidade se distingue de risco pois esse último remete a condições de debilidade de populações e grupos da sociedade. Já vulnerabilidade indica situações fragilizadas de indivíduos e a precariedade de acesso a direitos e à proteção social que eles encontram ao longo de suas vidas, decorrentes do baixo nível socioeconômico, da não participação no mundo do trabalho, ou de insuficiente remuneração do trabalho. É no cotidiano da vida dos indivíduos que se constituem essas precariedades e, para além da ausência de recursos, em geral, somam-se outras fragilidades - baixa escolarização, condições insuficientes de higiene, de nutrição, de acesso à saúde, relacionadas a moradias precárias, localizadas em ambientes degradados e sem condições sanitárias - atingindo questões fundamentais de direitos humanos e cidadania. Ademais, o conceito de vulnerabilidade é utilizado quando dicotomias como inclusão/exclusão, pobres/ricos não são suficientes para explicar situações sociais tênues (BRASIL, 2007), pois vulnerabilidade remete a carências dos benefícios da cidadania, estando, de alguma forma, associada à exclusão e à desvinculação social, à destruição da confiança a qual é importante "pilar do pertencimento social" (RESENDE; RIBEIRO, 2017, p. 390). Na discussão teórica há diferentes nuances de vulnerabilidade social, abrangendo questões de identidade, situações relacionadas a stress psicológico, aspectos econômicos, de direitos civis, de debilidade e restrições de autonomia, de liberdade e de autorrespeito, carência de bens e serviços, o que sugere uma certa imprecisão conceitual e, ao mesmo tempo, o quanto diferentes áreas de conhecimento anunciam tentativas de teorização a respeito. Resende e Ribeiro (2017), em diálogo com diferentes autores, acentuam a construção histórica da 
vulnerabilidade. Para eles a "vulnerabilidade estrutural" se refere à restrição de poder político, econômico e dos direitos civis, estando, inclusive, associada a "relações [...] de desigualdade produzidas e compartilhadas ao longo da história" (RESENDE; RIBEIRO, 2017, p. 381).

É importante, em meio à discussão teórica de vulnerabilidade social, retomar elementos legais e normativos vigentes na República Federativa do Brasil quanto ao tema da pobreza e da vulnerabilidade. A Constituição Federal de 1988 reafirma os direitos de cidadania, a importância da construção de uma rede de proteção social, a dignidade da pessoa humana e, dentre os compromissos do Estado, assinala a erradicação da pobreza e da marginalização, a promoção do bem de todos, sem nenhuma forma de discriminação ou preconceitos de raça, cor, idade, sexo e origem (BRASIL, 1988). Assim, na década de 1990 a segurança social passa a ser tratada "como bem público para alcançar todos os membros da sociedade" (SPOSATI, 2009 , p. 14). Trata-se, portanto, de uma proteção social que objetiva a universalidade, uma proteção social "vigilante, proativa e preservacionista" (SPOSATI, 2009, p. 21), isto é, proteção social implica em "tomar a defesa de algo, impedir sua destruição" (SPOSATI, 2009, p. 21), em voltar-se à preservação da vida. No debate de políticas de proteção social e, inclusive, do PBF, é preciso considerar o contexto de influências internacionais. Carmo e Guizardi (2018, p. 8) nos alertam que tais políticas, em meio a "determinações de organismos internacionais e pressões populares e políticas [...] [apontam para] a família como sujeito alvo das políticas públicas de seguridade social". O PBF bem responde a essa delimitação, ao constitui-se como um programa de transferência de renda voltado à família, como uma alternativa de proteção social não contributiva, mantendo-se "fora das relações de mercado, desmercantilizado" (SPOSATI, 2009, p. 23). Não há pagamento específico no PBF para que o serviço seja oferecido, nem no ato de atendimento nem de forma antecipada, mesmo considerando as condicionalidades que possam ser impostas.

No caso das políticas de proteção social não contributivas sabe-se que "o modelo de gestão deve estar apto não só a cadastrar beneficiários mas a vincular territorialmente os benefícios a um conjunto de serviços que fortaleçam as condições de cidadão" (SPOSATI, 2009, p. 24). No caso do PBF as condicionalidades de frequência à escola e o atendimento ao calendário de vacinação, endereçam para a dimensão de cidadania e são valorizadas como canais de inclusão. Assim serviços 
educacionais e de saúde precisam estar acessíveis às pessoas em vulnerabilidade que, atendendo aos critérios, podem cadastrar-se ao PBF.

Necessário se faz, entretanto, registrar algumas análises ao viés da compulsoriedade que transpassa certas políticas sociais. Sposati (2009, p. 26) relaciona tal obrigatoriedade à sua "funcionalidade ao mercado", ao modo de funcionamento da sociedade capitalista. No caso da condicionalidade relativa à frequência à escola, identifica-se uma face funcional ao modo de vida atual pois, interessa aos empregadores, indivíduos competitivos, voltados para resultados, trabalhadores com condições básicas de leitura e compreensão de, por exemplo, manejar com manuais de instrução de maquinário e interagir frente à forma de organização da vida em sociedade, cada vez mais normatizadora e individualista.

Aos sistemas públicos de ensino interessa ampliar os indicadores de matrícula e de conclusão de níveis escolares da população, frente aos compromissos nacionais e internacionais de melhoria de taxas de escolarização e de conclusão de etapas e níveis de escolarização. Aos sistemas de ensino também interessam índices de escolarização quantitativamente mais elevados devido a cálculos que os associam à idade dos estudantes e ao seu desempenho em testes padronizados cujos resultados, organizados na forma de indicadores sintéticos, permitem comparações regionais, nacionais e internacionais, bem como ranking entre regiões, escolas e países.

Críticas mais incisivas, veiculadas por Resende e Ribeiro (2017, p. 388), em diálogo com diferentes autores, postulam que políticas voltadas para superar a pobreza voltam-se, em sua grande parte, a dar acesso ao trabalho, o que, de alguma forma, sugere uma perspectiva não pronunciada de "reabilitação social" dos indivíduos em situação de vulnerabilidade, ou seja, "a intervenção pública visa reabilitar o pobre", frente ao padrão de funcionamento da sociedade capitalista, cada vez menos democrática. Argumentam ainda Resende e Ribeiro (2017, p. 388) "os vulneráveis são, ao mesmo tempo, atingidos em sua dignidade e moralmente responsáveis pelas consequências deletérias de sua indigência". Ademais, "as pessoas em situação de vulnerabilidade devem, em um só tempo, desenvolver suas capacidades de sobrevivência e limitar suas habilidades de se interrogar a si mesmo e ao mundo" (RESENDE; RIBEIRO, 2017, p. 389).

Por outro lado, resgatando argumentos para além das ressalvas que possam ser feitas ao PBF, Pires (2008) realiza um estudo acerca das informações socioeconômicas disponíveis no Cadastro Único do Governo Federal, considerando 
famílias beneficiárias do PBF, no município de Campinas. Sua pesquisa apresenta dados a respeito da situação dos domicílios tais como escoamento sanitário, abastecimento de água, bem como, perfil de idade, grau de escolaridade e sexo dos responsáveis pelos domicílios, indicando o quanto o PBF, como um programa de transferência de renda, contribuiu para a redução da pobreza e para a garantia de sobrevivência dos beneficiários.

Dando seguimento a esse artigo, propõe-se uma caracteriza o PBF, e depois, uma discussão e análise de práticas de gestão a ele relacionadas em um município da grande Porto Alegre.

\section{DESENVOLVIMENTO}

Inicialmente o PBF será discutido em algumas especificidades e, como ele se apresenta na região em que os dados de rede pública escolar foram coletados para, em sequência, indicar os caminhos metodológicos e apontar práticas e desafios em escolas públicas de educação básica.

\subsection{Programa Bolsa Família e educação: características e percepções}

O PBF criado pelo governo federal através da Medida Provisória № 132 em 2003 e depois convertido na Lei no 10.836 de 2004, vem se tornando, para as famílias em situação de pobreza e de extrema pobreza, uma forma de sobrevivência e de acesso aos direitos sociais básicos diante da situação de vulnerabilidade social (BRASIL, 2003, 2004). O PBF está vinculado à Secretaria Nacional de Renda de Cidadania (SENARC) responsável pela implementação de políticas relacionadas à distribuição de renda que atendem, de forma direta, às famílias com critérios de elegibilidade aprovados e inseridas no Cadastro Único do governo federal. Em 2004, o PBF atendeu a 3,6 milhões de famílias. Esse número aumentou dez anos depois da criação chegando a registrar mais de 14 milhões de famílias beneficiárias de acordo com os dados divulgados pela Secretaria de Avaliação e Gestão da Informação (SAGI) ${ }^{1}$ (BRASIL, 2020c). Com mais de quinze anos de existência, a abrangência e a relevância do programa no campo das políticas públicas, tornou-se referência nacional e internacional no enfrentamento da fome e da pobreza. Em nível nacional, o Instituto de Pesquisa Econômica Aplicada (IPEA) destaca o impacto do programa na vida das famílias de baixa renda (OSÓRIO; SOARES; SOUZA,

\footnotetext{
${ }^{1}$ Os dados específicos sobre o quantitativo de famílias atendidas referentes a cada ano do PBF podem ser consultados em: https://aplicacoes.mds.gov.br/sagi/vis/data3/data-explorer.php
} 
2011). Em âmbito internacional, a Organização da Nações Unidas (ONU $)^{2}$, enfatiza que o PBF se tornou um exemplo de política pública social, que atende de forma imediata à necessidade de suprir a carência de alimentação, assistência, saúde e educação dos menos favorecidos (PROGRAMA ..., 2011). O PBF está estruturado em três dimensões que são: transferência direta de renda; condicionalidades e ações complementares, bem como em seis princípios ${ }^{3}$ que alicerçam a conjuntura do programa: "Enfrentamento da pobreza e da desigualdade social; Proteção social não contributiva; Proteção social à família; Intersetorialidade; Gestão descentralizada; e Inclusão social" (BRASIL, 2018). Na primeira dimensão, o programa destina uma renda mínima mensal atendendo aos critérios de cada benefício e monitorando as famílias no âmbito do cumprimento das condicionalidades. Assim, além do chamado "benefício básico" ${ }^{4}$ há o benefício referente a jovens de 16 - 17 anos de idade, a gestantes e nutrizes, a crianças, bem como um benefício para a superação da extrema pobreza.

Como destacado por Soares e Sátyro (2009, p. 11), o PBF "não é um direito". Esta afirmação se justifica, uma vez que a lei de criação do programa, estabelece que depende da dotação orçamentária. Ou seja, a quantidade de famílias precisa estar de acordo com os recursos definidos no orçamento. Conforme normatização expressa no artigo sexto da lei de criação do programa (BRASIL, 2004), em seu parágrafo único, é atribuição do Poder Executivo a compatibilização da quantidade de beneficiários do PBF com as dotações orçamentárias existentes. Considerando, entretanto, que o Brasil é um país de desigualdades extremas onde "os $5 \%$ mais ricos detém a mesma faixa de renda que os demais 95\%" (GEORGES, MAIA, 2017, p. 6), é grande e urgente a necessidade de diminuição da desigualdade social, de erradicação da pobreza, de minimização da vulnerabilidade. Tendo em vista, o aumento de famílias beneficiárias e considerando as condições orçamentária para a efetivação do atendimento, abre-se espaço para discussões acerca dos termos da legislação. Ou seja o aumento do nível de pobreza da população vem se tornando um fator que demanda reflexão nesse sentido, considerando, inclusive, o aumento no quantitativo de pessoas extremamente pobres, registrado em 2018 (INSTITUTO

\footnotetext{
${ }^{2}$ Destaque atribuído ao PBF pela ONU em 2011.

${ }^{3}$ Informações sobre a descrição de cada princípio estão no Manual do Pesquisador Bolsa Família (BRASIL 2018, p. 8).

${ }^{4}$ Conforme consulta à Lei no $10.836 / 2004$. Valores de cada benefício estão disponíveis em Brasil (2015).
} 
BRASILEIRO DE GEOGRAFIA E ESTATÍSTICA (IBGE), 2019), e, especialmente, frente à pandemia Covid19.

Dada a complexidade na definição de linhas de pobreza, no Brasil é adotada a concepção de pobreza monetária ${ }^{5}$, que se configura través de "um valor que serve como linha de corte para diferenciar pobres e não pobres" (IBGE, 2019, p. 57). Para a pobreza, este valor está limitado em US\$5.50 e para extrema pobreza em US $\$ 1,9$, por dia. Considerando a variação da moeda norte-americana em relação à moeda brasileira, esse valor equivale a aproximadamente $R \$ 30,47^{6}$ e $R \$ 10,52$, que corresponde a $R \$ 914,00$ e $R \$ 315,00$ mensais cerca de $90 \%$ e $30,2 \%$ do salário mínimo em 2020 no Brasil, respectivamente.

$\mathrm{Na}$ segunda dimensão o PBF estabelece contrapartida das famílias beneficiárias através do compromisso com o cumprimento de condicionalidades em saúde e educação. $\mathrm{Na}$ saúde, as condicionalidades estão voltadas para a manutenção de vacinas em crianças menores de sete anos de idade e se houver gestantes na família a realização de pré-natal e consultas. Já no que se refere à educação, essas condicionalidades contemplam a matrícula na escola e a frequência de no mínimo $85 \%$ das aulas para as crianças e adolescentes de seis a quinze anos e de $75 \%$ para jovens que tenham entre dezesseis e dezessete anos de idade (BRASIL, 2020a). A terceira dimensão diz respeito a ações complementares, que neste caso, de acordo com Manual do Pesquisador Programa Bolsa Família (BRASIL, 2018, p. 5), "objetivam o desenvolvimento de capacidades das famílias e a superação de sua situação de vulnerabilidade."

O PBF funciona através da gestão compartilhada e descentralizada entre as instâncias governamentais, com atribuições desenvolvidas de maneira conjunta, tendo como base, o apoio financeiro do governo federal para Estados e municípios investirem no aperfeiçoamento da gestão do programa. A promoção dessas ações é de atribuição das instâncias do poder público federal, estadual, municipal e do Distrito Federal, bem como estendida à sociedade civil. Essas iniciativas sugerem que às famílias beneficiárias sejam oportunizadas possibilidades de sair da condição de vulnerabilidade em que se encontram. As características do PBF, portanto, focalizam a população pobre e extremamente pobre, e se materializa com o alívio

\footnotetext{
${ }^{5}$ Sugerido pelo Banco Mundial para "classificar as pessoas na pobreza. Essa linha foi adotada nas Sínteses de Indicadores Sociais de 2017 e de 2018 " e mantidas na síntese de 2019, publicadas pelo IBGE (2019, p. 58).

${ }^{6}$ Cálculo realizado com base no valor da cotação do dólar comercial correspondente a R\$ 5,54 (DÓLAR HOJE, 2020).
} 
imediato de carências, através da transferência direta de renda, recursos financeiros que minimizam as precárias condições de vida das famílias.

Com a unificação ${ }^{7}$ dos programas de transferência direta de renda que deu forma ao PBF, foi possível, em nível nacional, distribuir às famílias menos favorecidas, uma renda mínima para suprir necessidades básicas de sobrevivência. Em relação à repetência, Oliveira e Soares (2013, p. 22) afirmam que "há evidências que o PBF reduz a repetência de quem o recebe." Esses autores referem que, com o cruzamento dos dados do Cadastro Único, do Censo Escolar e do Projeto Frequência ${ }^{8}$, as análises indicam a influência direta do PBF no fluxo escolar, com a diminuição da repetência.

A ampliação dos índices de frequência indica a articulação das ações entre municípios, estados e governo federal. Cabe destacar a importância da alimentação escolar fornecida na escola, ou seja, além do recurso financeiro merece destaque para a sobrevivência das famílias a alimentação oferecida nas escolas aos alunos frequentes. O estudo sobre o tempo de permanência dos estudantes beneficiários na escola, relacionado ao impacto positivo do PBF e à condicionalidade da educação, aponta para "uma redução nas chances de evasão e faltas escolares", bem como para "significativa redução na desigualdade do tempo na escola inerente à população-alvo do programa” (NERI; OSÓRIO, 2019, p. 877). Em 2016, o Ministério do Desenvolvimento Social e Combate à Fome, atual Ministério da Cidadania (MDS), através dos boletins de acompanhamento da gestão do PBF apresentou um panorama do alcance do programa.

O Bolsa Família foi um dos principais fatores que contribuíram para que o Brasil cumprisse, com antecedência, os Objetivos de Desenvolvimento do Milênio (ODM): a meta da ONU de reduzir a fome e a pobreza extrema até 2015 à metade do que era em 1990 foi alcançada pelo Brasil em 2002. Ainda, a meta nacional de reduzir a porcentagem de pobres a $1 / 4$ da de 1990, apesar de mais ambiciosa, também foi cumprida e superada em 2008 (BOLETIM ..., 2016, p. 5).

De fato, por ser um programa federal o próprio ministério dá ênfase ao impacto significativo que ele alcança, embora se saiba que a redução da pobreza extrema tem se mostrado um desafio histórico no país e que, os ganhos se alcançados em um certo tempo e espaço, não o são para sempre, ou seja, não

\footnotetext{
${ }^{7}$ De acordo com o parágrafo único do Art. $1^{\circ}$ da Lei $\mathrm{n}^{\circ} 10.836 / 2004$ (BRASIL, 2004).

8 "É uma base de registro da frequência escolar das crianças beneficiárias do programa". (OLIVEIRA; SOARES, 2013, p. 7).
} 
permanecem indefinidamente, exigindo esforços redobrados e constantes. No caso do PBF, considerando o quantitativo de famílias que ainda seguem à margem da possibilidade de usufruir de direitos humanos $e$, das possibilidades de cadastramento para poder participar do PBF, muito há a fazer.

Dados de 2017 informam "13.676.038 milhões de famílias no PBF", sendo registrado o "valor médio do benefício: $R \$ 178,93$ ", que representa o percentual de $19 \%$ do salário mínimo correspondente ao ano, sendo "R\$ 2,4 bilhões pagos em benefícios diretamente às famílias" e do total de famílias, " $55 \%$ dos beneficiários são crianças e jovens até 20 anos." Destes, "cerca de 96\% dos estudantes de 6 a 17 anos cumprem a condicionalidade de educação" (BOLETIM ..., 2017, p. 5). Em 2018, na análise da frequência apresentada pela SENARC (BOLETIM ..., 2018), destacou-se a região Sul com 93,4\%, sendo o mais alto percentual de acompanhamento do país, seguida da região Sudeste, com 90,5\% e Centro-Oeste, com $89,2 \%$, em penúltimo a região Nordeste, com $88,2 \%$ e a região Norte na última colocação, com 87,7\% , o mais baixo número registrado neste período. Em 2019, a classificação das regiões em relação ao acompanhamento da frequência se manteve igual ao ano anterior inclusive, tendo atingido o maior registro de acompanhamento da frequência desde o início do programa (BOLETIM ..., 2019). De acordo com dados anteriores, a cobertura do PBF, tornou-se determinante no processo de minimização da vulnerabilidade social e contribuiu diretamente na redução da pobreza e favoreceu os indicadores educacionais. Nesse sentido, Silva et al. (2008, p. 55) afirmam que o programa necessita ampliar o alcance e um dos apontamentos passa pela "articulação com uma política macroeconômica e de redistribuição de renda."

Para a educação, o PBF tem assegurado o acesso à escola, a frequência escolar e tem contribuído para a continuidade da trajetória escolar de alunos(as) beneficiários(as). De acordo com Fernandes, Viana e Alves (2014) tanto no Ensino Fundamental quanto no Ensino Médio os estudantes beneficiários apresentam menor percentual de abandono escolar em relação aos estudantes não beneficiários, o que acena para o sucesso do PBF.

Cortes e rupturas do PBF foram matérias referidas pela imprensa brasileira, com ênfase na preocupação com as consequências dessas ações. Segundo Resende (2020), no ano de 2019 o novo governo travou os benefícios de cerca de um milhão de famílias em duzentos municípios mais pobres do país. A medida 
impediu que novos registros de famílias cadastradas fossem liberados, apesar de atenderem aos critérios de elegibilidade. Com a contenção na liberação e no acesso das famílias ao programa, surgiu novamente uma fila de espera, que voltou a aparecer depois de dois anos.

No que diz respeito à situação social, o estudo realizado por Osório, Soares e Souza (2011), publicado pelo IPEA, já apontava possibilidades para erradicar a extrema pobreza no Brasil.

\begin{abstract}
A erradicação é possível porque as evidências de que dispomos sugerem que o PBF só não é mais efetivo em reduzir a pobreza extrema devido ao baixo valor por família das transferências - insuficiente para que parte delas cruze a linha - e ao fato de que ainda há famílias extremamente pobres fora do programa. Reduzir a exclusão indevida é uma tarefa mais difícil que a de aumentar o valor das transferências; contudo, superados estes dois obstáculos, a erradicação da pobreza extrema pode ser alcançada por meio do PBF (OSÓRIO; SOARES; SOUZA, 2011, p. 50).
\end{abstract}

De fato, o programa vinha produzindo diminuição do quantitativo de famílias em situação de extrema pobreza, entretanto, o PBF descontinuado, ou até mesmo, mantido, mas sem implementação de outras políticas públicas que favoreçam a melhoria da qualidade de vida da população, a tendência é que, na sociedade brasileira, ocorra um retrocesso ou que o caminho em busca da efetivação do objetivo de erradicação da pobreza fique muito mais longo.

Portanto, compreende-se, que quanto mais famílias em situação de vulnerabilidade social obtiverem acesso aos benefícios de transferência direta de renda proporcionado pelo $\mathrm{PBF}$, maiores possiblidades se apresentam em relação ao acesso à educação, à permanência na escola e à melhoria da qualidade de vida. $O$ PBF, contudo, tem funcionado como um complemento das demandas mínimas de sobrevivência, não sendo suficiente para o enfrentamento da problemática da pobreza no Brasil. Desta forma, enfatiza-se a necessidade de melhorias nos serviços públicos e a implantação/implementação de políticas públicas em diferentes setores que favoreçam, assegurem e garantam o acesso aos direitos sociais à população menos favorecida.

\title{
2.2 PBF: dados atuais do Rio Grande do Sul, Região Metropolitana e município estudado
}


Nacionalmente e de forma comparativa, os dados de início e final do ano de 2019 indicam um retraimento, de 4,5\%, do PBF no Brasil, ou seja, uma variação negativa de 571.299 famílias beneficiadas no Programa. A situação do RS foi também de encolhimento do PBF. Ao longo de 2019, registrou-se, no RS, uma queda de $7,2 \%$ beneficiários, comparando dados de janeiro e novembro desse mesmo ano. Nesse estado - RS -, observa-se uma predominância de mulheres (75\%) como beneficiárias no PBF, portanto, como mulheres-chefes-de-família. Já quanto ao valor do benefício, no ano de 2019 , os $R \$ 174,46$ registrados como valor médio do benefício no RS, ficam "abaixo da média nacional de R\$191,08" (CONCEIÇÃO; MAIA, 2020).

$\mathrm{Na}$ Região Metropolitana de Porto Alegre, a variação negativa no ano, foi de $8 \%$ do total de benefícios que possuía, isso porque, mais de 10.000 famílias deixaram de ser beneficiadas (CONCEIÇÃO; MAIA, 2020).

Na página do MDS, ao consultar os "painéis de monitoramento" de "São Leopoldo/RS - Benefícios", observa-se que, também no município em estudo, ocorreu uma redução, nesse caso, na ordem de $10 \%$ da quantidade de famílias atendidas em 2019, considerando o número total de 7.708 beneficiários em maio de 2019 e, 6.929, em dezembro desse mesmo ano. Destaca-se que, no início de 2020 o total de famílias beneficiárias reduziu-se um pouco mais, pois somavam $6.154 \mathrm{em}$ fevereiro de 2020. Já o quantitativo de novos benefícios concedidos em abril de 2020 foi de 2.254, embora, no mês anterior, março de 2020, tenha ocorrido o cancelamento de 329 benefícios em São Leopoldo. Em agosto de 2020, somam-se 8.227 benefícios básicos concedidos em São Leopoldo, quantitativo esse, bem maior, frente aos 6.154, em fevereiro de 2020. Em outros termos, portanto, esses dados indicam que há uma dinâmica intensa no PBF, seja de ingressos e de cancelamentos de famílias beneficiárias, seja de tipos de benefícios concedidos para além do benefício básico (BRASIL, 2020b).

São Leopoldo é um município de médio porte, com uma população estimada, para 2020, de 238.648 habitantes, configurando, conforme site do IBGE, uma densidade demográfica de 2.083,82 habitantes por quilometro quadrado, e um Produto Interno Bruto (PIB) per capita de $\mathrm{R} \$ 33.905,58$. O Índice de Desenvolvimento Humano é alto, alcançando IDH de 0,739. A taxa de escolarização da população entre 6 e 14 anos de idade alcança um atendimento universalizado, de $96,8 \%$ (IBGE, 2018). 
O propósito desse artigo é analisar, em escolas e rede pública municipal, práticas de gestão desenvolvidas nesse cenário de vulnerabilidade social e políticas de proteção social, considerando, especialmente, as criadas para atender estudantes, em situação de vulnerabilidade social, beneficiários do PBF.

\subsection{Práticas criadas pela rede municipal de educação de São Leopoldo, frente a alunos beneficiários do PBF}

O termo práticas tem sentido "polissêmico" (SACRISTÁN, 1999, p.27) e aqui nessa pesquisa, acompanhando a discussão proposta por Sacristán (1999, p. 30), destaca-se que "só os indivíduos agem e não as instituições sociais"; só os indivíduos agem uma vez que a ação apela para a totalidade do sujeito. Ora, a educação e a gestão envolvem ações que envolvem processos e resultados que constituem ações entre pessoas, sobre pessoas e a partir de pessoas no contexto das sociedades. Assim, "tudo que em educação se relaciona com as ações humanas, levará o selo da expressividade da pessoa que age [...] agimos de acordo com o que somos e naquilo que fazemos é possível identificar o que somos (SACRISTÁN, 1999, p. 31). Cada um, portanto, constrói um eu singular e, por meio de ações "cada um constrói a própria diferença em relação aos demais e se torna singular ator de sua própria vida" (SACRISTÁN, 1999, p. 31). Compreender a dimensão individual da ação implica em concebê-la no contexto de relações sociais das quais cada um participa com outros seres humanos, pois a ação se dá em articulação com outros seres humanos, de forma que somos, a um só tempo, agentes e pacientes da ação, seres que se influenciam mutuamente. Conforme Sacristán (1999, p. 32) embora "as ações sejam radicalmente singulares, pode-se falar de estilos de ação compartilhados”. Tal compreensão de que os estilos de ação podem ser compartilhados, nos permite realizar, em termos de metodologia de coleta de dados, processos de discussão em grupo com equipes diretivas que atuam em escolas públicas de educação básica, de uma rede municipal específica a qual demonstra interesse de propor políticas e compreender a situação das escolas de sua rede, considerando as escolas que atendem, $30 \%$ de beneficiários do PBF, para mais, dentre o total de alunos matriculados. Da mesma maneira, fundamenta teórica e metodologicamente essa pesquisa a afirmativa de que "podemos entender a ação como empresa coletiva, como movimento social que junta as vontades dos 
indivíduos" (SACRISTÁN, 1999, p. 32), na forma de ação conjunta e com intencionalidade para impulsionar a ação.

No caso do município de São Leopoldo, a administração local acompanha e monitora escolas da rede. Para efeitos desse artigo, considera-se, práticas recentes, especialmente criadas para acompanhar as escolas com maior número de estudantes que participam do PBF.

Inicialmente identificou-se uma iniciativa do município em estudo, relacionada a estudo promovido pelo Conselho Municipal de Educação de São Leopoldo (CME/SL) em articulação com o executivo local, e socializada com o grupo de pesquisa da Universidade, estudo este intitulado "Escolas Municipais de São Leopoldo e Bolsa Família".

Tal estudo apontou o índice de infrequência por faixa etária dos estudantes e por região da cidade de São Leopoldo, abrangendo, também, matrícula, aprovados, reprovados, evadidos e transferidos. Ademais, o levantamento de dados considerou, por escola, o número total de estudantes matriculados e o quantitativo dos beneficiários do PBF. Assim, foram identificados aqueles estabelecimentos de ensino que tivessem, dentre os matriculados, mais de $30 \%$ de estudantes beneficiários do PBF, o que indicou que, quase $25 \%$ das escolas da rede, estavam nessa condição. Ora, se a ação envolve significados, valores e sentidos compartilhados de forma a caracterizar-se como uma "empresa coletiva" (SACRISTÁN, 1999, p. 32), então o estudo "Escolas Municipais de São Leopoldo e o Bolsa Família", produzido em interação entre o CME/SL e a Secretaria Municipal de Educação, evidencia a preocupação da sociedade local com a vulnerabilidade social e com a qualidade da educação proporcionada aos estudantes beneficiários do PBF matriculados na rede pública e seu aproveitamento escolar.

Destaca-se nesse artigo, uma das práticas de gestão que a rede municipal utiliza para acompanhar estudantes em situação de vulnerabilidade social a realização de um diagnóstico da rede no qual foi levado em conta a distribuição territorial da vulnerabilidade social. Destaca-se nessa prática de gestão a ação do colegiado local (CME/SL) e a socialização dos dados junto ao poder executivo da rede de educação básica, bem como o debate intersetorial com outras secretarias municipais de educação - Saúde, Direitos Humanos, Segurança - o que sugere uma intencionalidade compartilhada. 
Nessa rede, portanto, foi realizado um estudo com identificação das escolas com maior concentração de estudantes beneficiários do PBF e identificado o quantitativo de estudantes cuja faixa etária extrapolasse a idade considerada como "regular", norma essa, prévia e, de forma padronizada, definida para o ensino fundamental de sistemas públicos de educação básica. Registra-se que, de acordo com o Ministério da Educação a defasagem idade série é considerada quando o estudante está com, pelo menos, dois anos acima da idade designada para a série.

Ademais são identificados, por região da cidade, os evadidos, bem como a faixa etária de maior infrequência, isso, comparativamente, ao longo dos anos. $O$ trabalho abrangeu também o levantamento e análise do montante de estudantes infrequentes, dos que têm seus dados informados na Ficha de Comunicação de Aluno Infrequente (FICAI) a qual é um mecanismo criado em 1997, em parceria entre a Secretaria Estadual de Educação/RS, a Secretaria Municipal de Educação de Porto Alegre, o Ministério Público e Conselhos Tutelares, para acompanhar e controlar o abandono escolar.

Tal diagnóstico que incluiu também procedimentos pedagógicos e dificuldades que as escolas da rede enfrentavam, possibilitou que o poder executivo local propusesse medidas de enfrentamento e acompanhamento especialmente voltadas para escolas com maior número de estudantes beneficiários do PBF. Portanto, o diagnóstico realizado pelo $\mathrm{CME} / \mathrm{SL}$ em conjunto com a Secretaria Municipal de Educação e escolas, identificou aspectos problemáticos e analisou procedimentos pedagógicos da rede. Dentre os aspectos pedagógicos relevantes foram apontados: * projetos desenvolvidos pelas escolas sobre temas como música, literatura, tecnologias, cinema, ciências, dentre outros; * elementos relativos às interações no coletivo, incluindo referências ao coleguismo entre professores, alunos que desenvolvem boa relação com a escola, o grupo de profissionais da escola que se mostra engajado, unido, a comunidade que demonstra ser parte da escola bem como a equipe diretiva que atua de forma estreitamente integrada; * enfoque no pedagógico, seja pela menção a reuniões e colegiados escolares, seja traçando objetivos para que os alunos sejam autônomos, participativos, críticos e resolvam conflitos com tranquilidade. $O$ estudo também sistematizou aspectos que limitavam ou impediam, de alguma maneira, o trabalho pedagógico, tais como: *evasão de alunos no $7^{\circ}$. ano; "quadro incompleto de professores; *dificuldades de espaço na escola para desenvolver projetos e atender crianças da educação infantil; 
*dificuldades com a rede de apoio à saúde em especial atendimento psicológico; * necessidade de mais tempo para reuniões docentes em que ocorram reflexões acerca de práticas pedagógicas; * questões relacionadas à inclusão, dentre outras.

As análises procedidas pelo colegiado e executivo local, expressou de forma clara a necessidade de olhar, diferenciadamente, para as escolas que atendem, estudantes beneficiários do PBF, no caso do município se São Leopoldo, em taxa acima de $30 \%$ do total de alunos matriculados, em cada estabelecimento.

\subsection{Elementos teórico-metodológicos}

A metodologia utilizada, de cunho qualitativo, está relacionada ao interacionismo simbólico, dando valor à construção de significados pelos atores envolvidos. O foco da pesquisa volta-se para as interações e os sentidos que são atribuídos no cotidiano às ações na escola, aos modos de compartilhamento e formas de atuar, entender e interpretar os acontecimentos. Essas escolas constroem processos sociais que são significativos, envolvendo as equipes diretivas, professores, estudantes e comunidade atendida e, suas condutas e processos, expressos em falas, depoimentos, relatos de situações, são inteligíveis e partilhados com o grupo e articuladas aos seus contextos.

Para o desenvolvimento dessa perspectiva teórico-metodológica, definiu-se trabalhar com equipes diretivas com a finalidade de aprofundar a caracterização de práticas de gestão desenvolvidas em escolas, que tivessem, dentre os estudantes matriculados, mais de $30 \%$ como beneficiários do PBF. Com essas equipes realizouse a coleta de dados no formato designado de "discussão em grupo" (FLICK, 2009, p. 180). Tal discussão pode ser considerada como uma forma de entrevista em grupo que produz entre seus participantes, uma atmosfera estimulante ao debate, ao aprofundamento de temas e que se aproxima da maneira como usualmente as opiniões são trocadas, produzidas e manifestadas na vida cotidiana.

Vale lembrar que a Universidade local promoveu, mediante a iniciativa de um de seus pesquisadores e, antes da pandemia Covid-19, uma investigação para identificar práticas de gestão em tais escolas, na medida em que a discussão em grupo registra, como diríamos "uma voz conjunta", sem identificação da pessoa que a emite ou de seu vínculo institucional. Ressalta-se, portanto, que no texto do presente artigo, quando são registradas contribuições da discussão em grupo, não são identificados os emitentes do depoimento nem a escola a que pertencem. Esta 
decisão se justifica pois o foco de interesse situa-se na identificação de práticas que as equipes diretivas criam no dia-a-dia para enfrentar desafios que vão se configurando frente ao comprometimento da escola com a comunidade, seus estudantes e com a democratização da educação. Na metodologia adotada, portanto, o interesse não está em saber qual foi a pessoa que emitiu a informação e a qual escola pertence. Assim, não há identificação de falantes pois todos são membros de equipes diretivas. No desenvolvimento da coleta de dados foram adotados procedimentos de ética em pesquisa mediante a explicação dos objetivos do trabalho, utilizando-se carta de aceite para o executivo municipal e Termo de Consentimento Livre e Esclarecido para os membros das equipes diretivas que participaram da discussão em grupo.

Nesse estudo, o pesquisador, considerando a coleta de dados no formato de discussão em grupo, assumiu a posição de coordenador dos componentes de equipes diretivas que se dispuseram a participar, e, em sua atuação, cuidou para "não atrapalhar a iniciativa própria dos participantes", de forma a criar um espaço no qual a discussão ocorresse, "primariamente por meio da troca de argumentos" (FLICK, 2009, p. 185). Optou-se por essa estratégia de coleta de dados, entendendo, com Flick (2009, p. 186) que "Os enunciados e as manifestações de opinião são elaborados no contexto de um grupo, sendo que estes podem ser comentados, passando a ser objeto de um processo mais ou menos dinâmico de discussão" e de construção de argumentos. Assim, o pesquisador, durante o desenvolvimento da discussão em grupo, realizou mínimas intervenções que interviessem no direcionamento da dinâmica, de maneira a acomodar participantes muito falantes e que tendessem a monopolizar a palavra e a estimular os mais silenciosos, bem como a redirecionar a dinâmica para o conteúdo, ou para a rememoração de práticas.

\subsection{Práticas de gestão nas escolas}

A seguir encontram-se sistematizadas práticas de gestão identificadas a partir do depoimento de equipes diretivas de escolas de educação básica que possuem, dentre os estudantes matriculados, um grupo de mais de $30 \%$ de beneficiários do PBF. Tais práticas incluem e/ou indicam os desafios visualizados e/ou enfrentados, bem como compreensões a respeito da escola, especialmente frente a situações de vulnerabilidade social, nesse artigo identificada a partir da participação no PBF. 
2.5.1 Práticas de constatação, aceitação, investigação, flexibilização curricular e proposição referentes a desafios relacionados à idade dos estudantes e à sua permanência na escola

$\mathrm{Na}$ discussão em grupo ficou evidente que há uma postura de constatação do fenômeno da defasagem idade-série/ano e consciência dos profissionais quanto aos esforços dos estudantes em permanecer na escola. Identifica-se, também, uma postura investigativa, inclusive, interessada em conhecer melhor o perfil do aluno com idade acima do ano que frequenta, bem como, constatam-se falas relacionadas a ações de aceitação e outras que poderíamos chamar de ações propositivas. Em algumas escolas há turmas de aceleração o que se considerou como ação proativa, propositiva. Quanto a essa estratégia, assim se pronunciou um participante: "ano passado nós tivemos turmas de aceleração, uma turma de 21 alunos e terminou com 17 alunos. 2 evadiram e 2 reprovaram. E mesmo assim nós temos um número bem assustador". Também a oferta na escola de Educação de Jovens e Adultos (EJA) que está disponível em algumas escolas é apontada como uma possibilidade para compreender e enfrentar o problema da faixa etária muito alta para a frequência no ensino fundamental no turno diurno e, reduzir o abandono escolar dos alunos com idade mais elevada.

Aqui o depoimento das equipes diretivas acena para o que Dubet (2003, p. 41) aponta como "autoexclusão amena" em que os alunos escolhem ir para a EJA para preservar sua autoestima e dignidade, uma vez que vivemos em um momento histórico em que ao indivíduos é atribuído o dever de serem "autores de seus desempenhos, como seus responsáveis" (DUBET, 2003, p. 41). "Por parte dos professores essa estratégia de autoexclusão é percebida como uma crise de motivação, como uma maneira de se proteger dos desafios escolares e de escapar às críticas" (DUBET, 2003, p. 42). O diálogo que aqui está sendo proposto com François Dubet, autor que se refere à situação francesa, não implica que se esteja conformando a realidade das escolas públicas municipais de SL, e dos seus docentes, à realidade francesa ou à sua semelhança. Chamar François Dubet para discutir esses dados proporciona um recurso importante para questionamento e problematização das possibilidades de democratização da escola pública brasileira. Os participantes da pesquisa, membros de equipes diretivas de escolas públicas municipais de São Leopoldo, pode-se dizer que manifestam "aceitação" a respeito 
da escolha resignada dos estudantes por participar do EJA, uma vez que assim se manifestaram a respeito:

\begin{abstract}
"A modalidade EJA facilitou a permanência, porque antes eles saíam mais novos, mas saíam para o trabalho. Então quando eles começam a trabalhar, com 14, 15 anos, eles sabem que tem a possibilidade da EJA, então eles vão para EJA, não param de estudar. Já houve o tempo que eles saíam e paravam de estudar, iam trabalhar. Então a gente não tem tanta distorção no $9^{\circ}$ ano porque os mais velhos, eles mesmo acabam querendo ir para a EJA, porque facilita para quem trabalha, enfim, os mais velhos quando chegam em uma certa idade que eles veem que não dá mais, eles vão para a EJA". (Depoimento).
\end{abstract}

A permanência na escola, mesmo em faixa etária mais alta do que a esperada, afigura-se para alguns participantes da discussão em grupo, como um "avanço" frente à realidade brasileira de um passado recente - trabalho infantil. Portanto, contraditoriamente, registra-se uma conquista democrática quanto ao direito à educação de crianças pertencentes a grupos em vulnerabilidade social que permanecem como estudantes frequentando a escola, talvez em função da obrigatoriedade de comprovação de frequência escolar exigida pelo PBF, mas, por outro lado, com isso, têm a chance de estudar por um período de tempo maior. Ademais, como anteriormente foi assinalado, e de forma contraditória à afirmativa de "conquista democrática", o permanecer na escola por mais tempo, mas com situações percebidas "intuitivamente" pelos estudantes com idade de 17, 18, 19 anos, como desvinculação social do grupo mais infantil que compõe as turmas de ensino fundamental diurno, leva-os a procurar a EJA. O permanecer por mais tempo como estudante, pertencente ao sistema de ensino e frequentando a escola, poderá ser uma conquista que vem acompanhada de desafios para docentes e gestores escolares em decorrência de situações de retenção escolar e de descontinuidade ao longo da escolarização básica, bem como para enfrentar esse "clima" de "autoexclusão escolar". Ou seja, permanecem na escola como estudantes jovens com 16, 17, 18 e até 19 anos e essa situação traz um grande desafio para as escolas públicas de educação básica. O depoimento a seguir demonstra uma postura que remete ao que François Dubet discute e indaga: como fazer que a escola seja menos injusta. A contribuição de Dubet para a educação remete à questão da aceitação da diversidade e da multiplicidade de habilidades e condições de cada pessoa e, ao mesmo tempo, remete para a responsabilidade das redes públicas trabalharem para exercerem uma educação inclusiva, serem constituídas de escolas inclusivas, que consideram o conteúdo aprendido mas manifestam 
empatia e olham para cada indivíduo em sua especificidade, acreditando que todo o estudante é capaz de avançar.

"A questão da distorção tem vários pontos, muitas variantes, ela tem relação sim com a reprovação, com esse olhar da aprendizagem. Nesses territórios que a gente atua, sempre de vulnerabilidade e aí tem a questão da saída deles da escola. Eu recebi uma menina com 15 para 16 anos, para o 4 ano. Vindo de Gravataí. Chamei a mãe, fui ver a documentação dela e fui fazer uma avaliação e a menina há muitos anos não conclui o ano. Ela se muda porque não vai concluir. A prática que nós temos lá na escola é que quando chega um aluno com distorção, é necessário fazer esse histórico e já avançar, isso é independente. Tu olhas a aprendizagem, mas tu também olhas o indivíduo, ele foi privado. Ele não sabe dividir porque não foi ensinado, então a escola vai ter que pensar para dar esse suporte, mas também tem que avançar, porque certamente essa menina que vai fazer 16 anos ela não vai ficar junto com um aluno de 10 anos. Não sou favorável de encaminhar ela para EJA. Ela foi privada, então a gente vai ter que tentar fazer ... mesmo sabendo que eu avancei ela no $6^{\circ}$ ano e que ela pode ou não continuar na nossa escola, ela pode ir para uma outra escola e encontrar um outro perfil de professor, mas ela não pode ser culpabilizada por isso, ela nunca teve esse acompanhamento. Então essa é uma das variáveis, eu acho que no nosso território isso acontece muito, eu já até andei discutindo com a Central de Matrículas porque esse vai e vem não é só por troca de cidade. Isso claro que na questão de vínculo, na questão da aprendizagem desses alunos, isso vai influenciar diretamente na aprendizagem e na aprovação e reprovação". (Depoimento).

"Em relação à distorção o que me chama atenção é pensar que em 30 anos de profissão, quando a gente olhava e via que nossos alunos não completavam o $9^{\circ}$ ano, o ensino fundamental, $8^{a}$ série antiga, eles não chegavam tão velhos ao $9^{\circ}$ ano, porque eles saiam bem antes da escola. Abandonavam, em face ao trabalho infantil, eles saíam. Hoje na idade correta eles estão na escola, eles não conseguem sair, mas permanecem. Tanto, como a colega falou, a gente chega a ter alunos de 19 anos eles estão ali, não saíram da escola. Décadas atrás não era isso, os alunos saíam da escola com 11, 12 anos. Então não tinha um tempo para eles concluir o ensino fundamental'. (Depoimento).

\begin{abstract}
"Permanecem, apesar de todas as reprovações que eles carregam nas costas, às vezes tem esse aluno que tem 19 e reprovou três vezes no $6^{\circ}$ ano, fora os outros anos. Mas eles continuam, persistem". (Depoimento).

"O que mais nos incomoda é a questão da distorção idade dos alunos dos anos finais. A gente tem um número muito grande de alunos com distorção de idade, temos alunos até com 19 anos. Fomos fazer umas pesquisas essa semana com algumas questões bem específicas de distorção idade, alunos reprovados, alunos evadidos e foi bem preocupante o número de alunos com distorção de idade, principalmente nos anos finais. Nos anos iniciais nós também tínhamos no $4^{\circ}$ e $5^{\circ}$ ano mais ou menos uns 15 alunos, mas as séries finais foi o mais espantoso". (Depoimento).
\end{abstract}

Dentre os membros das equipes diretivas, há posições que não aceitam as transferências entre as escolas tendo em vista a possível desestabilização que a criança possa ter devido as constantes trocas e transferências entre escolas, sem motivo consistente. 


\begin{abstract}
"Eu acho que não deve ter troca de escola. Se a pessoa mora para o lado de lá da Av. Mauá, por exemplo, e ela consegue vir para cá, não tem por que ela procurar escolas mais longe. Porque ele troca de casa, troca de endereço e começa tudo de novo, daí tu desestabiliza aquele grupo, tu desestabiliza aquela criança e até ele conseguir vaga, até reconhecer os colegas e dali a pouco está ali um aluno que nem conseguiu saber o que aprendeu aquele ano, ele nem lembra mais. E quando tem problema, que eles precisem trocar, que tenha algum documento que responsabilize essa família no sentido de que nós estamos fazendo a nossa parte. Precisou mudar de escola por esse e esse motivo. Teve uma história de que eu pedi para uma mãe levasse a menina no médico pois ela me dizia que eu tinha que autorizar a menina a ir no banheiro a hora que ela quisesse, porque ela tinha problema urinário. Eu disse que queria um documento médico, de que ela tinha esse problema urinário, até porque é um problema sério. E ela ficou muito braba comigo e levou essa criança para outra escola. No mesmo ano". (Depoimento).
\end{abstract}

Uma prática que move as escolas e pode ser identificada a partir da verbalização das equipes diretivas presentes, é a questão que foi designada de flexibilização curricular e a reflexão a respeito do papel da Central de Matrículas que existe como componente da estrutura da Secretaria Municipal de Educação/SL (SEMED/SL) e que implica em práticas de gestão da rede frente a transferência, abandono, matrícula e frequência de estudantes. O "vaivém de estudantes", ou seja, mudança de escola, transferências, entre escolas da rede e de outras cidades, e as questões pedagógicas envolvidas, bem como as circunstâncias relativas à flexibilização curricular - tipo de flexibilização, tempo de flexibilização, tipo de avaliação, ...- são também desafios para a SMED/SL bem como para as escolas. Muitas vezes, quem assume a iniciativa da proposição da flexibilização curricular é, no âmbito escolar, a supervisão da escola que chama o professor, mas que, sendo uma prática de gestão nas escolas da rede torna-se também um desafio a ser enfrentado pela gestão da rede. Modalidades de compartilhamento e socialização de experiências e propostas de enfrentamento e superação de alguns problemas poderá ser um recurso de formação entre os gestores da rede com vantagens pela articulação do grupo e apoio mútuo que possa ocorrer, discussões ampliadas na rede e subsidiadas por estudos teóricos e acerca de abordagens pedagógicas associadas às experiências e a cada um dos casos compartilhados no grupo. Já no caso da adaptação curricular há orientações específicas de parte da gestão da rede, muitas vezes vinculada ao "laudo" da criança.

Quanto ao tema do acolhimento do aluno que passou por flexibilização curricular e vai transferido para outro estabelecimento escolar, compreendendo que este aluno necessita de um olhar compassivo e específico para suas condições, um 
componente das equipes diretivas contribui, inclusive sugerindo o compromisso da SMED/SL. Os debates ocorridos na discussão em grupo sugerem que as escolas municipais de São Leopoldo estão no rumo positivo de uma inclusão entendida amplamente, e, muitas equipes já se posicionam em direção, embora não pronunciem a expressão, à "escola inclusiva", aquela que abre espaço para todos. A escola inclusiva olha para a pessoa do aluno, considerando suas possibilidades especificas, são escolas que procuram ser um pouco menos injustas, de forma a reduzir a experiência de exclusão como uma das dimensões da experiência escolar de alguns alunos (DUBET, 2003) e procuram receber a todos os alunos, compreendendo as possibilidades de cada um, uma vez que a criança entra na escola como pessoa, e não como aluno com deficiência, ou como um aluno beneficiário do PBF, ou ainda, em vulnerabilidade social. Pode-se interpretar que, no dizer do participante cujo depoimento está inserido a seguir, o "olhar diferenciado" é aquele que verifica a idade que o estudante tem, e não se preocupa em demasia com os conteúdos que ele aprendeu ou deixou de aprender no seu percurso escolar. Ele é incluído nas turmas da escola considerando sua faixa etária. Assim, o entendimento de "escola inclusiva" poderia ter reduzido as dificuldades daqueles alunos que estão no ensino fundamental com 18 ou 19 anos, conforme foi registrado anteriormente nesse artigo frente a um depoimento de um participante da discussão em grupo.

\begin{abstract}
"Uma preocupação que nós temos e que já sugerimos para a Secretaria de Educação é que em algum lugar isto esteja documentado. Porque quando esse aluno, que sempre foi da minha escola e eu sempre entendi e tive um olhar e flexibilizei para ele, ele chegou ao $5^{\circ}$ ano e ele ainda não está alfabetizado, mas foi feito uma flexibilização... e de repente ele vai para uma outra escola e em lugar nenhum consta que ele tinha flexibilização curricular. Daí ele chega nessa outra escola e dizem: 'Como que esse aluno chegou ao $5^{\circ}$ ano?'. Isso num momento de transferência de matrícula não tem nenhum campo para isso e isso já foi uma sugestão que a gente comentou com a Secretaria, de que haja algum lugar para assinalar que esse aluno tinha uma flexibilização escolar, para que ele continue tendo esse olhar diferenciado". (Depoimento).
\end{abstract}

Como disseminar, desenvolver e fortalecer "esse olhar diferenciado" na escola e na rede pública municipal? Como desacomodar o professor frente à "reprovação"? Uma prática já referida anteriormente e que se constitui em estratégia bastante presente entre as equipes diretivas participantes da coleta de dados é a de levantamento de informações, a pesquisa junto aos estudantes. O relato a seguir detalha o objeto dos procedimentos de levantamento criados na escola. 


\begin{abstract}
"nesse perfil de comunidade, as crianças acabam por $N$ fatores abandonando a escola. Um fator que precede a evasão e que nos incomoda muito e nos preocupa é a infrequência, os alunos faltam e faltam. Isso acaba impactando, principalmente no ldeb, mas enquanto práticas de gestão, nós estamos fazendo levantamento do porquê das faltas, os motivos das faltas. os professores estão fazendo essa conversa direta com os alunos, tentando identificar e vendo de que forma a gente pode fazer algum tipo de intervenção. Em relação a questão da reprovação também vem sendo trabalhada com os supervisores nesse sentido porque é uma realidade, não só nessas 13 escolas [as que possuem percentagem de matrículas de beneficiários do PBF acima de 30\%], mas na rede de São Leopoldo. Há uma preocupação muito grande com a reprovação, principalmente no $3^{\circ}$ e no $6^{\circ}$ ano. Estamos inclusive preparando para nossa próxima reunião pedagógica, um trabalho de tratar destas questões da reprovação porque tem um reflexo da postura, da formação, do professor, mas daquela formação acadêmica do professor que acredita na reprovação, que acha que a reprovação é a solução e a gente agora tem que entrar nesta discussão da reprovação, de saber até que ponto ela é válida ou não, mas é complicado porque mexe muito com as coisas que aquele professor acredita". (Depoimento).
\end{abstract}

\title{
2.5.2 Práticas e compreensões a respeito da educação inclusiva e infrequência
}

ALguns depoimentos e expressões pronunciadas na discussão em grupo provocam a questão: A escola pública municipal de São Leopoldo ainda permanece na proposta que valoriza o olhar médico em relação às diferenças dos alunos? Que questionamentos podem ser feitos a respeito? A escola está tão burocratizada e intencionada a acatar a legislação que requer "laudo" para definir a situação do aluno, ao invés de descobrir propostas pedagógicas que incluam a todos? Sabe-se que a legislação brasileira é repleta de descontinuidades, de leis que avançam seguidas de outras que retrocedem nos caminhos da democratização e da inclusão para todos, é uma legislação que ainda insiste para o estudante se conformar às normas e não analisa que é sociedade e a escola que precisa mudar. Pergunta-se: a quem cabe esclarecer e propor o debate acerca da possibilidade de mudança rumo a um projeto pedagógico que ofereça uma educação realmente para todos, ao invés de insistir que o indivíduo mude e se ajuste ao padrão? $\mathrm{O}$ depoimento a seguir revela novamente práticas de "trocar a criança de escola". A resposta, encontra-se revelada na fala desse mesmo participante "o professor tem que ter um olhar para este aluno [...] é uma dificuldade que está nas questões pedagógicas", tendo em vista que o aluno "precisa seguir avançando". Todos da rede municipal defendem que o aluno precisa seguir avançando?

\footnotetext{
"muitas vezes são crianças com necessidades educacionais especiais que não tem laudo, que chegam com dificuldade e já por essa dificuldade eles acabam abandonando ou a gente procura a família, coloca a situação: "olha, quem sabe você procura uma avaliação médica, neurológica,
} 
psicológica" e a família não quer aceitar e acaba trocando o aluno de escola. O professor tem que ter um olhar para esse aluno e a escola tem que discutir a questão da flexibilização curricular. É uma dificuldade que está nas questões pedagógicas, ele precisa de uma flexibilização realmente. Para que ele possa seguir avançando. Isso é um empecilho que a gente encontra também, desse olhar, de que os pais não procuram atendimento médico, de que esse aluno venha ter um laudo, ou de que mesmo que ele não tenha esse laudo que tenha essa percepção de que ele precisa de uma flexibilização para seguir avançando, eu acho que tudo isso reflete na reprovação, evasão, infrequência". (Depoimento).

$\mathrm{Na}$ realidade brasileira, pode-se problematizar se o laudo não está, pelo menos em lguns casos, se configurando como um elemento burocrático, um elemento simbólico que, por si só, autoriza a ação. Entretanto, como fica a iniciativa e a proposta ativa da equipe gestora e dos professores da escola? A escola aguarda, esperando que a família procure atendimento médico e providencie um laudo? A escola recebe os estudantes transferidos e busca, junto a todos os seus professores recursos para ajudar esse aluno e proporcionar-lhe situações pedagógicas que o façam avançar? Ou a escola trabalha de forma a os enquadrar, os classificar dentro de uma escala, dentro de um padrão único e compartilhado entre todas as escolas da rede? Ou a rede trabalha em prol de uma cultura de atendimento a todos, considerando que cada ser humano tem suas características, condicionamentos e habilidades de forma que, mesmo em situação de transferência entre escolas da rede, o estudante não seja desencorajado em suas possibilidades? Se a SMED/SL providenciar na documentação de transferência dos alunos que "tenha um campo para assinalar que ele viveu um processo de flexibilização escolar" não permaneceremos, ainda, na lógica burocrática do atendimento à norma e da excepcionalidade, na lógica da exclusão? Flexibilização curricular, adaptação curricular, por que tantas diferenciações e tanta necessidade de documentação?

"Eu sinto que não tem uma orientação muito específica em termo de Secretaria para que aconteça a flexibilização. [...] no caso da adaptação curricular tem orientação específica, o aluno que tem o laudo, tem direito a essa adaptação. Tem as salas de recursos que os professores que trabalham com a inclusão auxiliam o professor a fazer esse documento, então no caso do aluno que tem um laudo, tudo está documentado é muito mais fácil de cobrar, mas no caso da flexibilização, que é quando o aluno tem uma dificuldade, não tem uma orientação.

O aluno sem laudo muitas vezes a gente pede ajuda do Serviço de Apoio ao Estudante, pessoal de atendimento educacional especializado para que faça, pelo menos, um atendimento com aquele aluno e aí junto com os professores a gente vê, onde é que aquele aluno precisa da flexibilização, o tipo de flexibilização: é de tempo, é o tipo de avaliação... Aí a gente vê, mas é um grupo de professores com a supervisão e o SAE. Porque tem crianças que a gente vê que tem sim algo, mas a família nunca foi atrás.

O grupo tem que estar sensível para fazer essa flexibilização, porque nós sabemos que tem professores que 'não, não sabe, não vai' então eu acho 
que o grupo todo tem que pensar 'vamos flexibilizar, porque se não facilitar, ele não vai adiante' então o nosso grupo é sensível e ele faz isso. É como a colega disse, se fosse registrado, então a outra escola também deveria fazer a flexibilização, mas não é o que acontece.

A flexibilização, tu não envias para a outra escola. Se a outra escola entrega. OK. Ela pode entregar ou não. Diferente de quando tem um laudo, que vem junto do histórico. Particularmente, eu cobro bastante da Secretaria essa normatização. Eu acho que enquanto rede, a gente precisa ter um olhar um pouco mais equilibrado. Porque se a gente faz tantas discussões, buscando a garantia do direito do sujeito, como é que a gente deixa para a escola tomar essa decisão? As vezes até tu conseguir descobrir esta história anterior.... é da nossa realidade essa questão da transferência dos alunos. Eles vão e voltam várias vezes ao longo do ano e até tu conseguir resgatar a história desse sujeito na outra escola, daqui a pouco, já terminou o ano. Havendo essa normatização no mínimo dentro da nossa rede, facilitaria bastante. Não somente para a questão de flexibilização, mas para várias outras questões. Eu estou fazendo desse jeito e você, faz como? Como vocês agem lá na sua escola? Eu acho que poderíamos avançar nossa discussão enquanto escolas se tivesse essa normatização". (Depoimento).

Alguns relatos acenam para a importância da formação continuada crítica, questionadora das práticas, por isso na fala seguinte está registrada uma postura de auto questionamento, de revisão de seus próprios pressupostos e formas de agir.

"Acho que eu me desmontei mais quando eu entendi o trabalho de inclusão
e comecei a entender o que que representa essa inclusão. De uma
professora, responsável pela sala de recursos, sentar e me dizer 'O que tu
entende por esse serviço?' e aí tu tem que ser extremamente humilde e
dizer 'Não sei' e ela dizer que a sala de recursos funciona de tal e tal forma,
que na rede ela funciona assim e na nossa escola ela trabalha desse jeito.
Inclusão é pensar em como tu vai fazer com que aquele teu aluno seja
atendido diante de aqueles objetivos tu tens para teu ano dentro das
capacidades dele, dentro daquele trabalho que tu vai fazer com teu grupo. E
aí tu repensas não só ele, mas todo teu trabalho e repensa teu grupo. Isso é
uma dificuldade que eu entendo exatamente pela minha dificuldade de
entender, que eu entendo que muitos colegas e uma grande maioria não
consegue fazer. E muito disso vai aparecendo exatamente por essa
distorção. Por isso mais uma vez eu digo, é uma normatização sim
enquanto rede, a gente vai assumir esse compromisso enquanto rede, e
esses professores a gente vai pensar os momentos de formação para que
eles sejam efetivos para gente garantir isso". (Depoimento).

No diálogo que se desenrolou na discussão em grupo, como afirmamos na metodologia desse trabalho, a argumentação dentre os participantes se aprofunda e amplia instigando a todos os componentes a apresentarem seus pontos de vista e continuarem a debater, a refletir com os demais. $\mathrm{Na}$ discussão acerca da "flexibilização curricular" o depoimento que segue demonstra, possivelmente, pelo emprego do termo "concepção", que o caminho para uma "escola inclusiva" está em gestação na rede municipal de São Leopoldo, está sendo progressivamente construído. As posições são contraditórias acerca da flexibilização, pois há quem expresse e seja favorável à normatização de parte da SMED, à restrição da 
autonomia da escola, quem vê a escola como um local de obediência burocrática e a rede como um espaço de cobrança de comportamentos padronizados e moldados pela norma, e há quem considere que se trata de uma "concepção". Ora, as concepções são construídas dinamicamente, a rede pode trabalhar na direção de construir uma concepção de escola inclusiva? Possivelmente, em direção a uma proposta de escola para todos, sem discriminação, a expressão "trata-se de uma concepção" esteja no início do debate. Mas é preciso considerar que será um debate longo, envolvente.

\begin{abstract}
"Para mim isso é uma concepção, entende? Até nós, enquanto gestores, temos o que é um trabalho árduo com os professores, mas se eu recebo um aluno assim, eu já tenho que prever que ele teve uma flexibilização, mesmo que isso não esteja em lugar nenhum. Eu posso até buscar, por exemplo, ir lá e conversar na escola para buscar mais subsídios [...], então a gente liga perguntando para ver da onde a gente parte até para começar, para ter uma base. Mas para mim isso é concepção. Na própria escola acontece isso na sala dos professores, de falar sobre isso e é uma mudança que é gradual e tem que partir de nós mesmos". (Depoimento).
\end{abstract}

Na metodologia de discussão em grupo, como são mínimas as intervenções que o coordenador realiza, pode-se observar, analisando a transcrição do material, que ideias mais consolidadas entre os presentes emergem e desaparecem das falas dos presentes. Há também cobranças em relação aos diferentes serviços e possíveis atendimentos realizados na rede.

\begin{abstract}
"O quanto a escola assume papéis que não são seus? A gente vai assumindo porque ninguém assume, mas está muito fácil de tu continuar assumindo e os outros serviços não assumirem. Faz mais de 2 anos que não temos avaliação dos estudantes. E se não tem não avaliação, não tem acompanhamento com neuro, não tem atendimento com fono, não tem atendimento com o fisio e a gente tem professores na sala de recursos que não tem formação para isso e vai pensando as atividades para fazer esse aluno evoluir e crescer nesses aspectos que estão dificultando a sua aprendizagem". (Depoimento).
\end{abstract}

As equipes diretivas manifestaram preocupação com a questões de infrequência e em relação ao que chamaram "aluno que falta rotineiramente" e a valorização da relação da família com a escola.

"Como é que tu estabeleces enquanto rede esse acompanhamento da frequência escolar? Porque uma FICAl só se consegue encaminhar se o aluno não volta à escola. E esse aluno que falta rotineiramente? Ele vem uma, duas vezes por semana e ele não volta... Aquele documento fica trancado dentro da escola. Não vai acontecer nada.

Os nossos alunos que têm mais de 15 anos, estão tudo trabalhando. Mas essa família, não vê na escola aquele papel que ela cumpre, que ela deveria estar cumprindo. Porque a escola para muitos não é importante enquanto um ambiente de aprendizagem, porque muitas vezes esses pais não conseguem ter essa concepção. 
Eu ouvi esses tempos de um pai... ele tem duas meninas de 7 anos que ingressaram esse ano no $1^{\circ}$ ano, obrigadas, e ele disse que não vai fazer diferença para a vida delas elas estudarem. Porque ele não estudou, estudou um pouquinho mais, até pela questão do trabalho e ele conseguiu me verbalizar isso, e quantos que não conseguem verbalizar? 'Não tem importância... Tem tanta gente que estuda e não consegue ter sucesso na vida'. E o que seria esse sucesso? Então eu me contento com aquilo ali. Como ele disse, vou trazer obrigado... E disse: 'Se tu quiser mandar conselho tutelar na minha casa pode mandar, não tem problema, porque eu vou repetir para eles isso aí. (Depoimento).

Em uma rede de escolas públicas ocorrem situações bastante complexas, muitas vezes relacionadas à interações com as famílias, aos serviços que ali foram criados, bem como a problemas de infraestrutura do prédio e arredores.

"A gente tem colocado essas famílias para dentro da escola e temos
conversado um pouco com eles para eles verem como é importante eles
ficarem com essas crianças dentro da escola, vindo o máximo de frequência
possível... porque hoje, [com essa chuvarada] eles são infrequentes, eles
não conseguem sair de casa, eles não tem guarda-chuva, rua alagada, não
tem calçada.... hoje é um dia que a nossa frequência cai bastante. Mas a
gente fala para eles que tragam essas crianças o máximo possível porque
vai ser muito importante e 'veja só os avanços que o teu filho tá tendo, a
gente já mudou isso, a gente já cresceu um pouquinho e a gente vai
conseguir avançar para algumas coisas". (Depoimento).

Em vários depoimentos a família aparece como ator importante e que precisaria estar mais próxima da escola. Por outro lado, fica também explicito o ambiente de drogadição e tráfico a que os estudantes estão submetidos e o quanto as escolas e as equipes diretivas e professores se compadecem e se sentem comprometidos com os alunos em situação de vulnerabilidade. $\mathrm{O}$ ambiente de tráfico e de drogadição disseminada são faces da vulnerabilidade social que trazem desafios para a escola, seus professores e para a sociedade local. As escolas buscam as famílias como apoios nos processos relacionados à escolarização das crianças e jovens, mas, muitas vezes as famílias desafiam os professores, não colaboram ou não compreendem a dedicação dos professores.

"No último dia das mães a gente fez também um show de talentos na escola,
no sábado de manhã e preparou um chá para as mães, com doces e
salgados... 218 mães, nunca tinha vindo tantas. No lado da escola tinha um
grupo de voluntários fazendo galeto, para arrecadar fundos, e o galeto teria 250
cartões e as 11 as pessoas poderiam retirar. Dessas 218 mães, 8 cartões
foram adquiridos por mães e 242 por outras pessoas que não são mães. A
comunidade escolar que tem $50,43 \%$ das mães usuárias do cartão bolsa
família. Isso não explica tudo, porque mesmo com essa renda, tem recurso
para drogas..., mas para ajudar a escola do filho não tem. O dia que era um chá
gratuito, que era uma homenagem. Mas a cultura da contrapartida de ajudar
não tem, quanto menor a faixa salarial, menor é a participação. Menos
importância as famílias veem de fazerem vir enquanto a rua está alagada em
dia de chuva, ou de buscar o boletim, ou de ir em um evento". (Depoimento). 
"Eu fiquei pensando... A escola pode até ser a mesma, mas os alunos não. Eles estão muito além. Eu acho que o professor tem que correr muito atrás, porque eles são diferentes, as famílias são diferentes também. A gente teve uma situação que é triste, mas ao mesmo tempo engraçada. A professora chama a mãe do aluno para conversar, fala para o aluno 'eu quero falar com a tua mãe na próxima aula' só que nem sempre o professor sabe a história do aluno. A gente que está ali na equipe sabemos mais. Mas o aluno veio desesperado me falar: 'mas professora, tu tem que falar pra ela que a minha mãe não pode vir'. Porque a mãe dele está com tornozeleira e ela pode vir até um pedaço da rua, e se ela passar daquele pedaço, sei lá, apita... e daí, poxa vida. Daí eu falei para a professora que a mãe não poderia vir e expliquei o porquê, daí ela me disse: 'que horror'... é uma coisa diferente. Uns anos atrás, mãe de aluno era mãe de aluno, como professor era professor. Hoje, mãe de aluno é diferente. O aluno é diferente, ele tem situações diferentes. (Depoimento).

"Então a gente tem esse planilha, então ali a gente vai fazendo apontamentos, avanços, o que melhorou, o que a gente vinha apontando e o que não deu, e na nossa comunidade, que é uma comunidade vulnerável, muita questão de drogas, as crianças estão à margem passíveis a todo tipo de vulnerabilidade, carências afetivas e emocionais, então a gente vai pontuando esses casos que tem casos familiares, porque aquele aluno que não está se alfabetizando tem uma situação, de negligencia, de abandono, em todos os sentidos, infrequência. Então assim a gente faz os apontamentos e encaminhamentos e se leva esses encaminhamentos adiante. $O$ que a gente percebe que a demanda é tão grande e a gente não consegue dar conta é que a gente faz os encaminhamentos e a família não se responsabiliza em cumprir, a gente coloca a responsabilidade, registra em ata mas a família não leva, porque daí eu tenho que me deslocar até o centro, então a gente já vem sugerindo que esse atendimento seja descentralizado para auxiliar nesse sentido, nessas comunidades carentes, eles têm muita resistência nesse deslocamento". (Depoimento).

\section{3 À GUISA DE CONCLUSÃO}

O cenário brasileiro convive com a presença da vulnerabilidade social que também perpassa as escolas ao longo de muitos anos. $O$ não atendimento de grupos em situação de vulnerabilidade social aponta ao crescimento da desigualdade junto a uma parcela significativa da população brasileira que não ascende a melhores condições de vida. Por ser um programa social, que está direcionado ao enfrentamento da pobreza, o PBF se configura através da transferência direta de renda com condicionalidades à população menos favorecida uma importante política pública direcionada à melhoria da qualidade de vida da sociedade, dependendo, para sua expansão e atendimento, da disponibilidade financeira do governo.

A importância do PBF tanto para os indicadores sociais quanto para os educacionais, é inegável; a manutenção de muitas famílias em condição de desassistência afeta a situação social e educacional dos mais vulneráveis, incluindo crianças, jovens, gestantes e nutrizes. Em se tratando da educação, a infrequência e 
a evasão escolar, problemáticas apontadas pelos gestores escolares, tendem a se elevar em decorrência da ausência do benefício. Por meio da condicionalidade da educação, o PBF se articula às escolas públicas e dessa relação sobressaem resultados indicados como significativos no campo educacional. Para a educação, o PBF tem contribuído, no sentido de apontar à frequência dos alunos com contributos para o quantitativo de matrículas, relação essa, entre programa e educação, que se apresenta também articulada ao compromisso das famílias A permanência das famílias no PBF, tornou-se elemento relevante, embora não suficiente, uma vez que são necessários outros apoios e encaminhamentos sociais junto a famílias em vulnerabilidade social, em especial relacionados ao mercado de trabalho. A desassistência remete à preocupação com a possibilidade de diminuição tanto no acesso quanto na permanência dos estudantes beneficiários, e aumento de crianças no mercado de trabalho, especialmente em atividades informais, uma vez que os dados e análises sugerem reflexos específicos na escola pública e, de forma ampla, na educação. Entretanto apenas a presença do benefício não é suficiente. Populações atendidas pelo PBF não estão isentas de ilícitos e de problemas de tráfico e consumo de drogas. A análise realizada demonstra a necessidade de práticas pedagógicas tanto em nível das redes como das escolas que se mostrem sensíveis às necessidades dos estudantes. Os desafios que atingem as escolas também alcançam a gestão das redes - distorção idade/ano; fuga de jovens para a EJA; múltiplas trocas entre escolas em um só ano; necessidade de flexibilização curricular; infrequência e educação inclusiva, para todos; estudantes que faltam rotineiramente; famílias que não valorizam educação escolar; inclusão de alunos com dificuldades de aprendizagem e necessidades específicas; por fim, a necessidade de repensar o todo do trabalho escolar.

Dados da pesquisa sugerem que, no âmbito da escola há práticas relativas a constatações, e, em outros casos até de pesquisas para melhor identificar o contexto de vida dos estudantes. Há também ações proativas inovadoras muito relacionadas a acolhimento, sensibilidade, compaixão e profissionalismo dos docentes e equipe de gestão que demonstram sensibilização para com a situação dos estudantes. Um grande desafio a ser enfrentado em ambos os níveis de gestão é o relativo a normas e exigências padronizadoras em meio aos procedimentos institucionalizados na rede e frente à autonomia escolar. 


\section{REFERÊNCIAS}

BOLETIM SENARC: acompanhamento e análise do Programa Bolsa Família e do cadastro único para programas sociais. Brasília, DF: Ministério da Cidadania. Secretaria Nacional de Renda de Cidadania, ano 2, n. 18, 2016. Disponível em: http://www.mds.gov.br/webarquivos/sala_de_imprensa/boletins/boletim_senarc/2016 /201612_Boletim\%20Senarc\%20N.18_dezembro_2016.pdf. Acesso em: 02 ago. 2020.

BOLETIM SENARC: acompanhamento e análise do Programa Bolsa Família e do cadastro único para programas sociais. Brasília, DF: Ministério da Cidadania. Secretaria Nacional de Renda de Cidadania, ano 3, n. 30, 2017. Disponível em: http:/www.mds.gov.br/webarquivos/sala_de_imprensa/boletins/boletim_senarc/2017 /Boletim\%20Senarc\%20N\%20\%2030_Dezembro_2017.pdf. Acesso em: 27 jul. 2020.

BOLETIM SENARC: acompanhamento e análise do Programa Bolsa Família e do cadastro único para programas sociais. Brasília, DF: Ministério da Cidadania. Secretaria Nacional de Renda de Cidadania, ano 3, n. 40, 2018. Disponível em: http://www.mds.gov.br/webarquivos/sala_de_imprensa/boletins/boletim_senarc/2018 /Boletim\%20Senarc\%20N\%20\%2040_OUTUBBRO.pdf Acesso em: 27 jul. 2020.

BOLETIM SENARC: acompanhamento e análise do Programa Bolsa Família e do cadastro único para programas sociais. Brasília, DF: Ministério da Cidadania. Secretaria Nacional de Renda de Cidadania, ano 4, n. 51, 2019. Disponível em: http://www.mds.gov.br/webarquivos/sala_de_imprensa/boletins/boletim_senarc/2019 /Boletim\%20Senarc\%20N\%20\%2051.pdf. Acesso em: 27 jul. 2020.

BRASIL. [Constituição (1988)]. Constituição da República Federativa do Brasil de 1988. Brasília, DF: Presidência da República, 1988. Disponível em:

http://www.planalto.gov.br/ccivil_03/constituicao/constituicao.htm. Acesso em: 17 jul. 2020.

BRASIL. Lei n. 10.836, de 9 de janeiro de 2004. Cria o Programa Bolsa Família e dá outras providências. Brasília, DF: Presidência da República, 2004. Disponível em: http://www.planalto.gov.br/ccivil_03/_ato2004-2006/2004/lei//10.836.htm. Acesso em: 17 jul. 2020.

BRASIL. Medida provisória n. 132, de 20 de outubro de 2003. Cria o Programa Bolsa Família e dá outras providências. Brasília, DF: Presidência da República, 2003. Disponível em:

http://www.planalto.gov.br/ccivil_03/mpv/antigas_2003/132.htm. Acesso em: 17 jul. 2020.

BRASIL. Ministério da Cidadania. Benefícios do Programa Bolsa Família. Brasília, DF: Ministério da Cidadania, 2015. Disponível em: http://mds.gov.br/assuntos/bolsafamilia/o-que-e/beneficios/beneficios. Acesso em: 24 jul. 2020.

BRASIL. Ministério da Cidadania. Guia para o acompanhamento das condicionalidades do Programa Bolsa Família. Brasília, DF: Ministério da Cidadania, 2020a. Disponível em: 
http://www.mds.gov.br/webarquivos/publicacao/bolsa_familia/Guias_Manuais/Acomp anhamento_condicionalidades.pdf. Acesso em: 25 jul. 2020.

BRASIL. Ministério do Desenvolvimento Social. Bolsa Família e cadastro único: painel de monitoramento. Brasília, DF: MDS, 2020b. Disponível em:

https://aplicacoes.mds.gov.br/sagirmps/bolsafamilia/painel.html. Acesso em: 27 jul. 2020.

BRASIL. Ministério do Desenvolvimento Social. Manual do pesquisador: Programa Bolsa Família. Brasília, DF: MDS, 2018. Disponível em:

https://aplicacoes.mds.gov.br/sagirmps/ferramentas/docs/manual_do_pesquisador_g estao_bolsa_familia_semlogo.pdf._Acesso em: 27 jul. 2020.

BRASIL. Ministério do Desenvolvimento Social. Secretaria de Avaliação e Gestão da Informação (SAGI). Data explorer. Brasília, DF: MDS, 2020c. Disponível em:

https://aplicacoes.mds.gov.br/sagi/vis/data3/data-explorer.php. Acesso em: 27 jul. 2020

BRASIL. Ministério do Trabalho e Emprego. Secretaria de Políticas Públicas de Emprego. Departamento de Estatística Qualificação. Aspectos conceituais da vulnerabilidade social. Brasília, DF: MTE, 2007. Disponível em:

https://docplayer.com.br/8044969-Aspectos-conceituais-da-vulnerabilidade-socialconvenio-mte-dieese.html. Acesso em: 18 jul. 2020.

CARMO, Michelly Eustáquio, GUIZARDI, Francini Lube. O marco social da vulnerabilidade social. Cadernos de Saúde Pública, Rio de Janeiro, v. 34, n. 3, art. e00101417, 2018. Disponível em: https://www.scielo.br/pdf/csp/v34n3/1678-4464csp-34-03-e00101417.pdf. Acesso em: 05 jul. 2020.

CONCEIÇÃO, João; MAIA, Marilene. 10 mil famílias foram desligadas do Bolsa Família em 2019 na Região Metropolitana de Porto Alegre. In: INSTITUTO Humanitas Unisinos (IHU). São Leopoldo, 20 fev. 2020. Disponível:

http://www.ihu.unisinos.br/167-noticias/observasinos/596454-10-mil-familias-foramdesligadas-do-bolsa-familia-em-2019-na-regiao-metropolitana-de-porto-alegre. Acesso em: 26 jul. 2020.

DÓLAR HOJE. Dólar comercial. [S. I]: Dólar Hoje, set. 2020. Disponível em: https://www.dolarhoje.net.br/dolar-comercial/. Acesso em: 28 set. 2020.

DUBET, François. A escola e a exclusão. Cadernos de Pesquisa, São Paulo, v.119, p. 29-45, 2003.

FERNANDES, Flávio Cireno; VIANA, Iara; ALVES, Cecília Brito. Ensino básico e trajetória escolar dos estudantes do Programa Bolsa Família. Cadernos de Estudos Desenvolvimento Social em Debate, Brasília, DF, n. 18, p. 50-60, 2014. Disponível em:

https://aplicacoes.mds.gov.br/sagirmps/ferramentas/docs/Caderno\%20de\%20Estudo s\%2018_final.pdf. Acesso em: 25 jul. 2020.

FLICK, Uwe. Introdução à pesquisa qualitativa. Porto Alegre: Artmed, 2009. 
GEORGES, Rafael; MAIA, Katia. A distância que nos une. São Paulo: Oxfam Brasil, 2017.

INSTITUTO BRASILEIRO DE GEOGRAFIA E ESTATÍSTICA (IBGE). Síntese de indicadores sociais: uma análise das condições de vida da população brasileira: 2019. Rio de Janeiro: IBGE, 2019. Disponível em:

https://biblioteca.ibge.gov.br/visualizacao/livros/liv101678.pdf. Acesso em: 27 jul. 2020.

INSTITUTO BRASILEIRO DE GEOGRAFIA E ESTATÍSTICA (IBGE). São Leopoldo, RS. Rio de Janeiro: IBGE, 2018. Disponível em:

https://cidades.ibge.gov.br/brasil/rs/sao-leopoldo/panorama. Acesso em: 26 jul. 2020.

JANCZURA, Rosane. Risco ou vulnerabilidade social?. Textos \& Contextos, Porto Alegre, v, 11, n. 2, p. 301-308, 2012. Disponível em:

https://revistaseletronicas.pucrs.br/ojs/index.php/fass/article/view/12173. Acesso em: 20 jul. 2020.

NERI, Marcelo C.; OSORIO, Manuel Camillo. Bolsa Família, tempo na escola e motivações estudantis. Revista de Administração Pública, Rio de Janeiro, v. 53, n. 5. p. 859-878, 2019. Disponível em:

http://bibliotecadigital.fgv.br/ojs/index.php/rap/article/view/80120. Acesso em: 27 jul. 2020.

OLIVEIRA, Luís Felipe Batista de; SOARES, Sergei S. D. Impacto do Programa Bolsa Família sobre a repetência: resultados a partir do Cadastro Único, Projeto Frequência e Censo Escolar. Brasília, DF: IPEA, 2013. Disponível em:

https://www.ipea.gov.br/portal/images/stories/PDFs/TDs/td_1814a.pdf. Acesso em: 25 jul. 2020.

OSÓRIO, Rafael Guerreiro; SOARES, Sergei; SOUZA, Pedro Herculano Guimarães Ferreira de. Erradicar a pobreza extrema: um objetivo ao alcance do Brasil.

Brasília, DF: IPEA, 2011. Disponível em:

https://www.ipea.gov.br/portal/images/stories/PDFs/TDs/td_1619.pdf. Acesso em: 25 jul. 2020.

PIRES, André. Bolsa Família e políticas pública universalizantes: o caso de um município paulista. Cadernos de Pesquisa, São Paulo, v. 38, n. 134, p. 341-366, 2008.

PROGRAMA Bolsa Família é exemplo de erradicação de pobreza, afirma relatório da ONU. In: NAÇÕES UNIDAS. Notícias. Brasília, DF, 07 dez. 2011. Disponível em: https://brasil.un.org/pt-br/58463-programa-bolsa-familia-e-exemplo-de-erradicacaode-pobreza-afirma-relatorio-da-onu. Acesso em: 20 jul. 2020.

RESENDE, Carolina Costa; RIBEIRO, Luiz Paulo. Breve ensaio sobre o conceito de vulnerabilidade social: exclusão social, trabalho, democracia e empoderamento.

Percurso Acadêmico, Belo Horizonte, v. 7, n. 14, p. 378-400, 2017.

RESENDE, Thiago. Bolsonaro trava bolsa família em cidades pobres e fila chega a 1 milhão. Folha de São Paulo, São Paulo, 10 fev. 2020. Disponível em: 
https://www1.folha.uol.com.br/mercado/2020/02/bolsonaro-trava-bolsa-familia-emcidades-pobres-e-fila-chega-a-1-milhao.shtml. Acesso em: 02 ago. 2020.

SACRISTÁN, J. Gimeno. Poderes instáveis em educação. Porto Alegre: Artmed, 1999.

SILVA, Maria Ozanira Silva e et al. O Bolsa Família no enfrentamento à pobreza no Maranhão e no Piauí. São Paulo: Cortez; Terezina: Ed. da UFPI, 2008.

SOARES, Sergei; SÁTYRO, Natália. O Programa Bolsa Família: desenho institucional, impactos e possibilidades futuras. Brasília, DF: IPEA, 2009. Disponível em: https://www.ipea.gov.br/portal/images/stories/PDFs/TDs/td_1424.pdf. Acesso em: 25 jul. 2020.

SPOSATI, Aldaíza. Modelo Brasileiro de proteção social não distributiva: concepções fundantes. In: BRASIL. Ministério do Desenvolvimento Social e Combate à Fome e à Pobreza. Concepção e gestão da proteção social não contributiva no Brasil. Brasília, DF: MDSCFP : UNESCO, 2009. p. 13-55. Disponível em:

http://www.mds.gov.br/webarquivos/publicacao/assistencia_social/Livros/concepcao _gestao_protecaosocial.pdf. Acesso em: 25 jul. 2020. 